\title{
Connessione tra saperi. Il contributo delle scienze grafiche nella ricerca in ambito medico
}

\author{
Enrico Cicalò \\ Marta Pileri \\ Michele Valentino
}

Abstract

Questo articolo discute il contributo apportato dalle Scienze Grafiche alla ricerca in ambito medico-sanitario e analizza le relazioni tra i due ambiti della conoscenza indagando le opportunità di interazione legate alle prospettive di ricerca più attuali. L'articolo si focalizza sui diversi strumenti grafico-visivi che possono favorire il progresso scientifico e sostenere i progetti di ricerca, presentando uno stato dell'arte su cui basare le relazioni di interazioni tra due ambiti apparentemente distanti ma che, come la storia ci dimostra, possono sviluppare fertili sinergie.

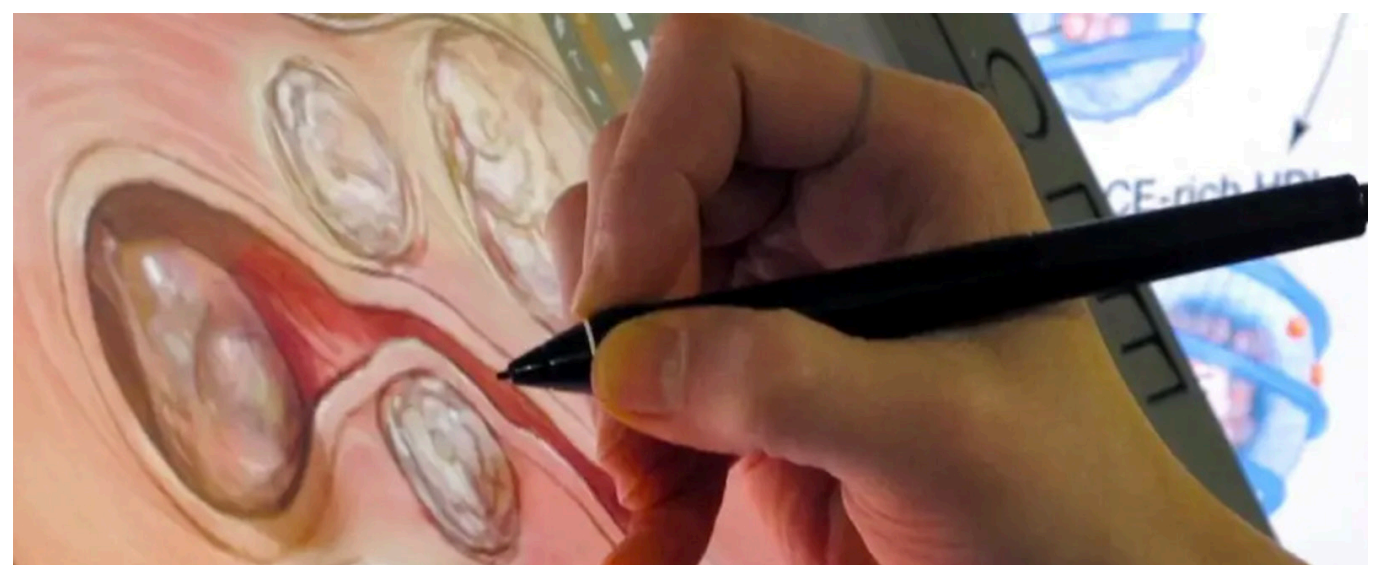




\section{Introduzione}

Per il loro essere inediti, i temi di ricerca emergenti si collocano spesso al confine tra gli ambiti tradizionali del sapere, in aree interstiziali in cui diventa necessario un approccio interdisciplinare che obbliga all'integrazione di molteplici conoscenze, tradizioni disciplinari, linguaggi e sensibilità. Ė questo il caso della visualizzazione medica, ambito di indagine emergente e allo stesso tempo storicamente consolidato, al confine tra scienze grafiche e scienze mediche.

L'illustrazione medica ha assunto nel corso della storia del pensiero scientifico un ruolo fondamentale nella costruzione e nella comunicazione della conoscenza, configurandosi come una componente essenziale dei metodi di indagine scientifica. Per le discipline mediche si è così reso necessario fare propri gli strumenti di rappresentazione grafica in modo da poter sviluppare le ricerche, delineando nuovi ambiti di indagine e nuove professionalità trans-disciplinari che coinvolgono le competenze grafico-visive.

Fig. I. II sistema arterioso, foglio 19, manoscritto Manoscritto Ashmole 399, fol. I8r. Xll secolo, da: < www.bodleian.
ox.ac.uk> (consultato 20 marzo 2021).

Fig. 2. Andrea Vesalio, De humani corporis fabrica, 1543, p. 197, da. <https:// commons.wikimedia. org/> (consultato il 20 marzo 202I)
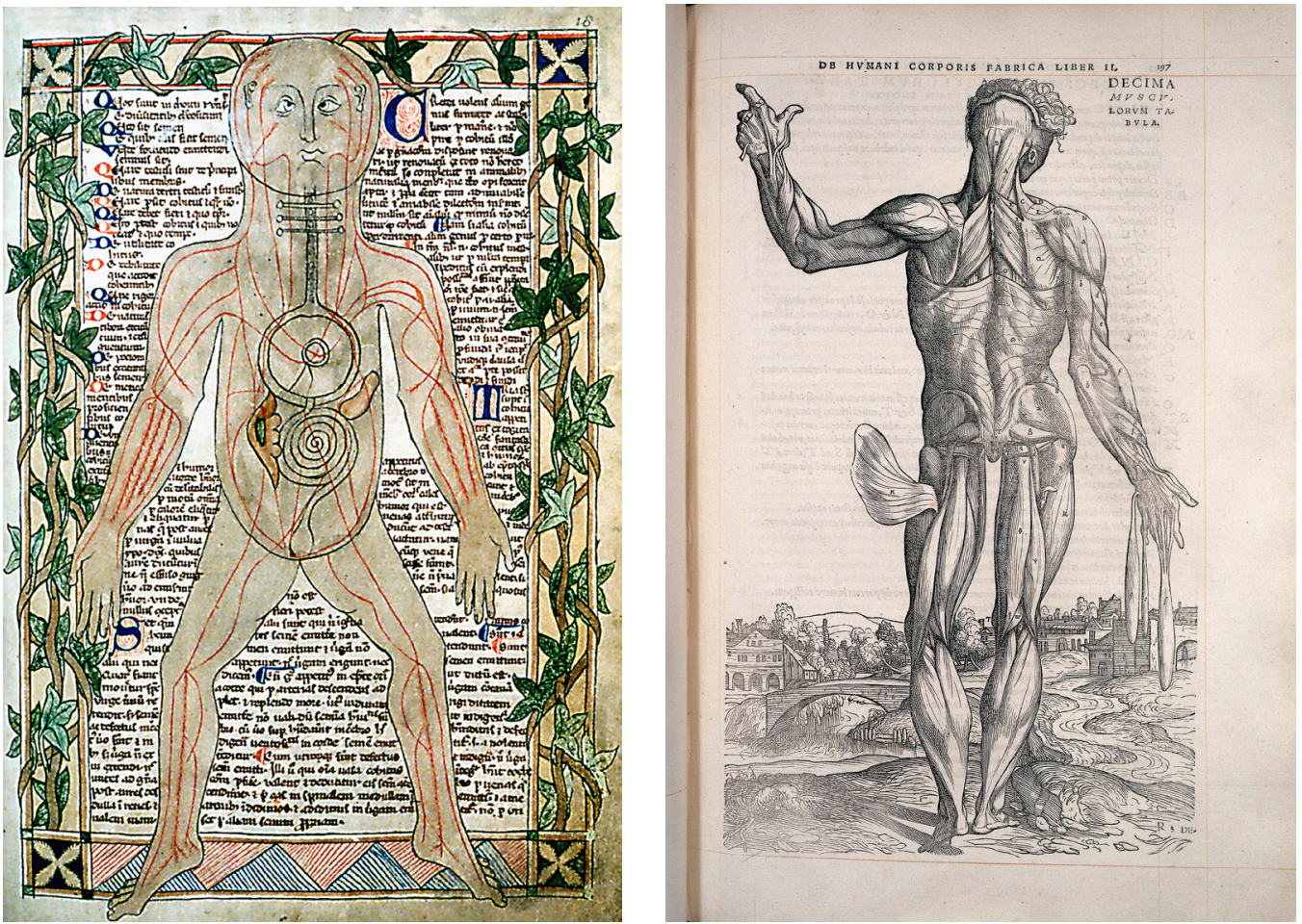

\section{Scienze grafiche e scienze mediche. Connessione tra saperi e distanze disciplinari}

Come la storia e la tradizione dell'illustrazione medica dimostra (figg. I-4), le visualizzazioni forniscono da sempre delle interfacce indispensabili per esplorare, comprendere e comunicare contenuti in ambito medico-sanitario [Hajar 20 I I]. Questo tipo di traduzioni grafiche della conoscenza hanno sempre permesso la trasmissione di informazioni attraverso rappresentazioni finalizzate a diversi scopi: per tradurre visivamente e potenziare il processo conoscitivo, per coinvolgere nei processi decisionali, per sensibilizzazione l'opinione pubblica su temi medico-sanitari di interesse generale e, infine, per divulgare e trasmettere contenuti di tipo scientifico.

Il campo di applicazione delle scienze grafiche in ambito medico è ancora oggi al centro del dibattito scientifico. Le modellazioni 3D, insieme alle traduzioni in immagini 2D per una facile interpretazione o per la creazione di illustrazioni statiche, animate o interattive, si con- 
Fig. 3. Leonardo da Vinci, principali organi e sistemia vascolare e urino-genitale di una donna, I $507 \mathrm{ca}$, da: $<$ https:// commons. wikimedia.org/> (consultato il 20 marzo 2021)

Fig. 4. Disegno delle cellule di Purkinje (A) e delle cellule di granul (B) del cervelletto di piccione, Santiago di piccione, Santiago Instituto Santiago Ramón Yatito Santiago Ramón y Cajal, Madrid, Spagna, da: <https://commons. wikimedia.org/> consultato il 20 marzo 2021) figura come l'ultima evoluzione della lunga storia dell'illustrazione medico-scientifica. Inoltre, un'ampia gamma di tecnologie di visualizzazione digitale tra cui la realtà virtuale e aumentata, il 3D stereografico e i dispositivi aptici viene oggi sperimentata e applicata nell'ambito della comunicazione con i pazienti e della formazione per i medici, della diagnostica, della visualizzazione e della simulazione medica.

I ricercatori operanti nell'area medica stanno studiando come la computer grafica possa dare stimolo al progresso della ricerca in ambito medico [Parslow, Elliot Green 197I].Tuttavia, anche se a livello internazionale si manifesta una forte attenzione alle potenzialità della visualizzazione medica, questa appare ancora non pienamente esplorata allinterno della comunità dei ricercatori del Disegno. Sebbene siano state discusse le relazioni tra i metodi e gli strumenti di rappresentazione tradizionali dell'architettura e le visualizzazioni in ambito medico e anatomico [Bianchini 2019; Casonato 2019, Càndito 2020], siano state esplorate le possibilità di applicazione delle tecniche di simulazione in relazione a particolari patologie [Capone, Lanzara 2020; Pecora 2020] e sia stata avviata una riflessione sul contributo delle scienze grafiche in ambito medico [Cicalò, Valentino 2019], esiste un campo di indagine ancora in gran parte da esplorare che può avere interessanti prospettive sia nell'ambito della ricerca che della didattica delle discipline del Disegno.
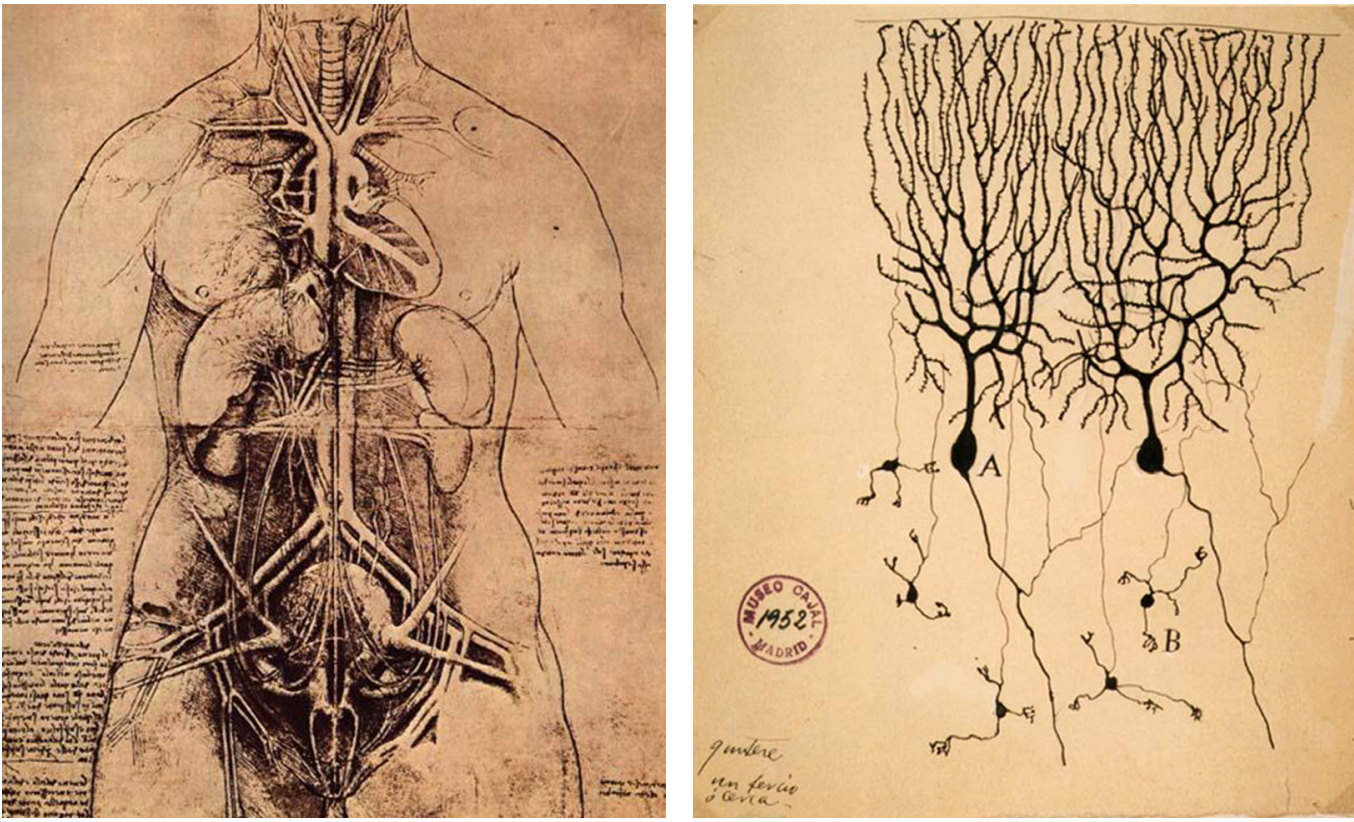

\section{Il contributo delle scienze grafiche alla ricerca in ambito medico}

In questo articolo vengono esplorati alcuni tra i principali campi di applicazione delle discipline grafiche nel settore medico. Dalla discussione vengono esclusi gli ambiti specifici relativi alla mera acquisizione di medical image data, legati all'uso di strumenti capaci di restituire automaticamente immagini per la diagnostica medica [cfr. Lawonn, Smit, Bühler, Preim 20 I 8]. L'attenzione viene invece rivolta a tutti quei settori in cui le competenze grafiche consentono di costruire immagini mediante tecniche di produzione e post-produzione che richiedono l'applicazione dei metodi, delle tecniche e degli strumenti della rappresentazione grafica e della comunicazione visiva, propri dunque delle scienze grafiche. Nella consapevolezza che ciascuna delle categorie di supporti grafico-visivi qui di seguito esposta meriterebbe una trattazione autonoma, si presenta un quadro - non esaustivo ma significativo - dei possibili contributi delle scienze grafiche alla ricerca in ambito medico, secondo un ordine che rispecchia la loro applicazione nelle diverse fasi della ricerca medica. 


\section{Raccolta dati}

Comunicazione e promozione di progetti di ricerca collaborativi

L'elaborazione di programmi di comunicazione visiva dei progetti di ricerca può contribuire alla costruzione delle reti di ricerca, soprattutto in considerazione del fatto che gli studi in ambito medico possono beneficiare dell'effetto di call for action (fig. 5) veicolato attraverso il web e i social media, capaci di ampliare il numero di soggetti coinvolti e dunque il campione di studio, soprattutto per il coinvolgimento di partecipanti non raggiungibili attraverso i canali tradizionali e le reti consolidate [Topolovec-Vranic, Natarajan 20 I6]. I social media si stanno dunque affermando come canali di comunicazione utili a identificare e reclutare potenziali partecipanti agli studi clinici e ad altre forme di ricerca [Gearhart 20 I 5; Gelinas et al. 20 I7; Whitaker, Stevelink, Fear 20 I7] attraverso la diffusione di contenuti visivi, che per la loro immediatezza e facilità di lettura possono dare un contributo significativo ai processi di comunicazione e divulgazione [Cicalò 20।8].

\section{Interpretazione dati}

Visualizzazione dei dati medico-sanitari

L'elaborazione di supporti grafici per la visualizzazione dei dati statistici e delle informazioni raccolte nel corso della ricerca può facilitare l'interpretazione dei risultati e supportare le decisioni. Sebbene in ambito medico sia ormai condivisa la convinzione che le immagini possano essere un potente mezzo di comunicazione, risulta ancora necessario investire nella ricerca nel campo specifico dell'elaborazione di visualizzazioni [Connor 2009; Gelman, Unwin 20 I3; Pocock, Travison, Wruck 2007]. È necessario infatti poter scegliere accuratamente la visualizzazione più efficace e la tipologia di illustrazione più adeguata, rispettare i principi fondamentali della comunicazione visiva [Cicalò, Menchetelli 2020] attraverso il coinvolgimento di discipline esterne all'area medica e investire maggiormente nella realizzazione di visualizzazioni che possono richiedere un maggior dispendio di energie, ma che possono contribuire al miglioramento della comunicazione dei risultati delle ricerche per supportare i processi decisionali [Duke et al. 2015] (fig. 6).

Fig. 5. Visual abstract per la campagna social finalizzata al reclutamento di unità operative per la partecipazone alla ricerca dedilaco riguardante le colecistectomia laparoscopica che prevede collaborazione professioalità nell'ambito della comunicazione, dell'infografica e della visualizzazione dati (2020).

Fig. 6. Omar Nema, Abhi Kumbara, visualizzazione dati sulle relazioni tra costi dimensioni dell'ospedale, dimensioni dell ospec qualità del risultatı ed esperienza del paziente, 2016, da: < https://arca (cols (consultatoil 20 marzo 2021).

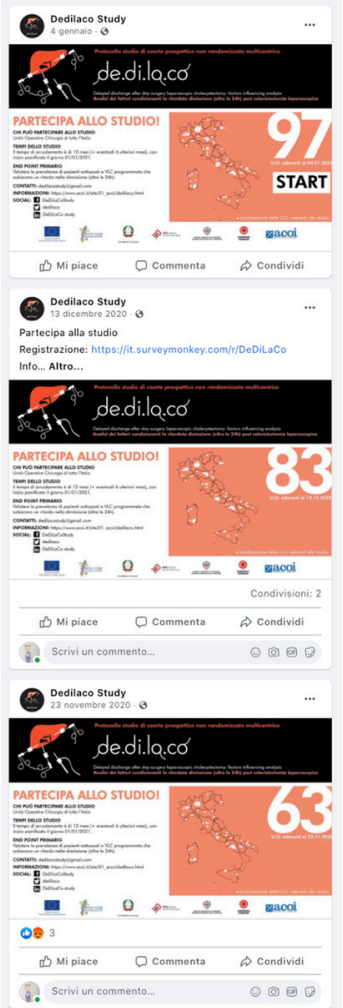

LOW COST HOSPITALS

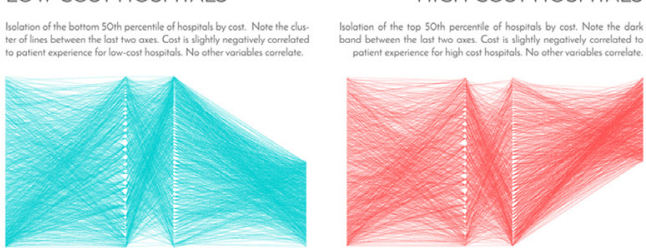




\section{Mappe sanitarie}

Un aspetto importante della ricerca sanitaria è lo studio dei fattori di rischio per le malattie considerate "ambientali" in quanto legate a fattori dipendenti dal contesto fisico [Listorti, Doumani 200 I; Prüssstün, Corvalan 2007]. La mappatura delle malattie e la valutazione del rischio ambientale sulla base di dati geospaziali è diventata un metodo ormai consolidato [Bergquist, Rinaldi 20 I 0; Richardson et al. 20 I3]. I sistemi di informazione geografica (GIS), il telerilevamento (RS), i sistemi di posizionamento geografico (GPS), le statistiche spaziali e altre applicazioni digitali hanno reso possibile tradurre in mappe le serie di dati rilevati nel corso delle ricerche mediche. II GIS si è così consolidato come uno strumento utile per raccogliere, esplorare, visualizzare e analizzare i dati sanitari in modo grafico [Hendrickx et al. 2004; Cringoli et al. 2005; Yang et al. 2005; Rinaldi et al. 2006; Brooker 2007] (fig. 7). Nell'ultimo decennio, inoltre, si è sviluppata una pubblicistica scientifica specializzata su questi temi, che ha determinato l'affermazione di riviste dedicate come International Journal of Health Geographics e Geospatial Health.

Fig. 7. Mappa per l'analisi e il monitoraggio de fenomeni legati al Covid-19, da <https:// www.esri.com/> (consultato il 20 marzo 2021).

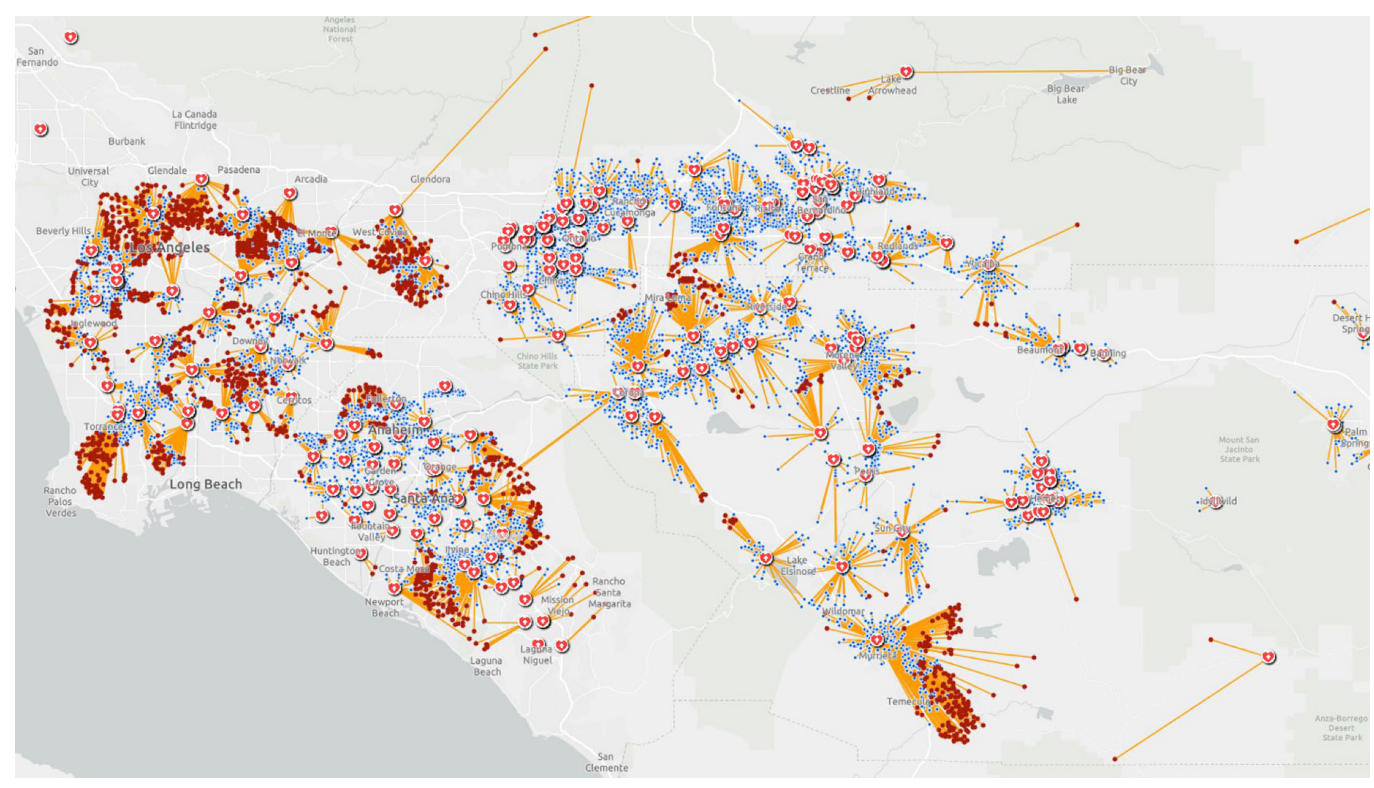

Divulgazione risultati

Illustrazioni mediche

La raffigurazione del corpo umano è stata da sempre centrale nello sviluppo della rappresentazione della conoscenza, a partire dalle pitture rupestri e dalle sculture primitive sino ai nostri giorni. Con il progresso scientifico i testi medici hanno poi iniziato ad essere accompagnati da illustrazioni che sono diventate parte integrante del processo di trasmissione della conoscenza. Gli illustratori si sono così affiancati ai medici per divulgare i loro studi e le loro scoperte e a volte le due personalità - del disegnatore e dello scienziato - sono andate a coincidere definendo una nuova figura professionale e un ambito disciplinare a sé stante [Tsafrir, Ohry 200 I], testimoniato anche da diverse pubblicazioni specializzate come il Journal of Visual Communication in Medicine dell'Institute of Medical Illustrators, The Journal of Biocommunication della Association of Medical Illustrators e della BioCommunications Association. Oggi l'illustrazione statica è ancora un formato di comunicazione visiva molto diffuso, ma la comunità di illustratori-medici ora include anche animatori, modellatori, designer di user-experience, specialisti multimediali, direttori artistici e altre tipologie di visualizzatori medico-scientifici [Bucher 2016] (figg. 8, 9). 
Fig. 8. Illustrazione medica diVictoria Mulloc (da: Association Européenne des Illustrateurs Médicaux et Scientifiques: <https:// www.aeims.eu/artists/> (consultato il 20 marzo 2021)

Fig. 9. Illustrazione medica di Luca Guerriero (da: Association Européenne des Illustrateurs Médicaux et Scientifiques: <https:// www.aeims.eu/artists/> (consultato il 20 marzo 2021)
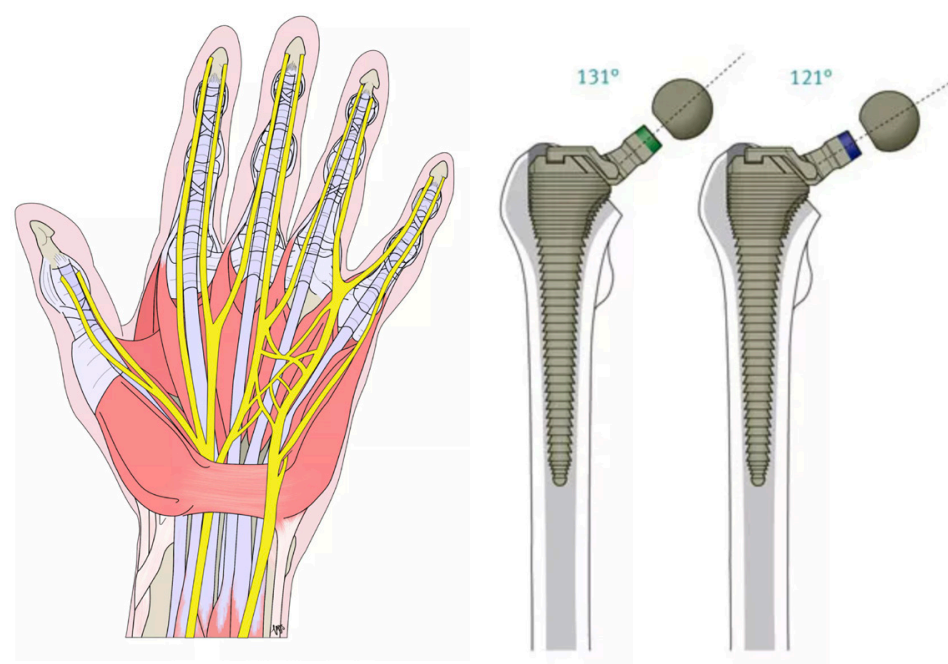

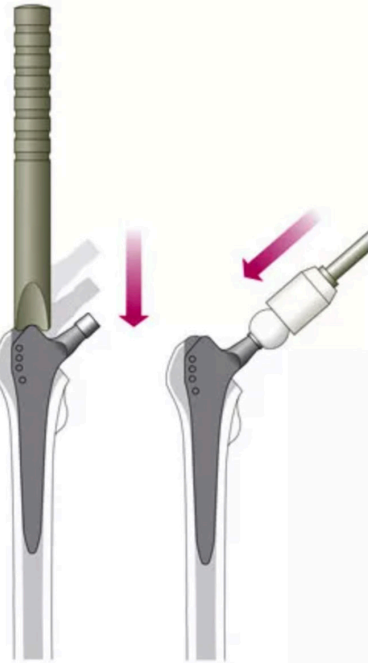

Visualizzazioni anatomiche tridimensionali

Le visualizzazioni mediche possono essere incluse in un ambito specifico facente parte della più ampia visualizzazione scientifica che affonda le sue radici nell'illustrazione anatomica e si esprime oggi nella computer graphics, attraverso la quale è possibile acquisire e archiviare i dati geometrici tridimensionali e gli algoritmi utili alla rappresentazione [Preim, Bartz 2007]. Le tecniche di visualizzazione tridimensionale possono essere utilizzate nella diagnosi, nella pianificazione del trattamento, nella comunicazione medico-paziente [Lawoon et al. 20 I8], nella formazione degli studenti che possono meglio comprendere la complessità della struttura anatomica [Battulga et al. 2012] (fig. 10) e più in generale nell'analisi e nella ricerca clinica [Parslow, Elliot Green 197I].

Terapia

Comunicazione visiva nell'interazione medico-paziente

L'elaborazione di supporti visivi alla comunicazione con il paziente può favorire la trasmissione di contenuti nella comunicazione medico-paziente [Austin et al. 1995]. L'uso della narrativa grafica è stata discussa e sperimentata in ambito medico da vari ricercatori, dimo-

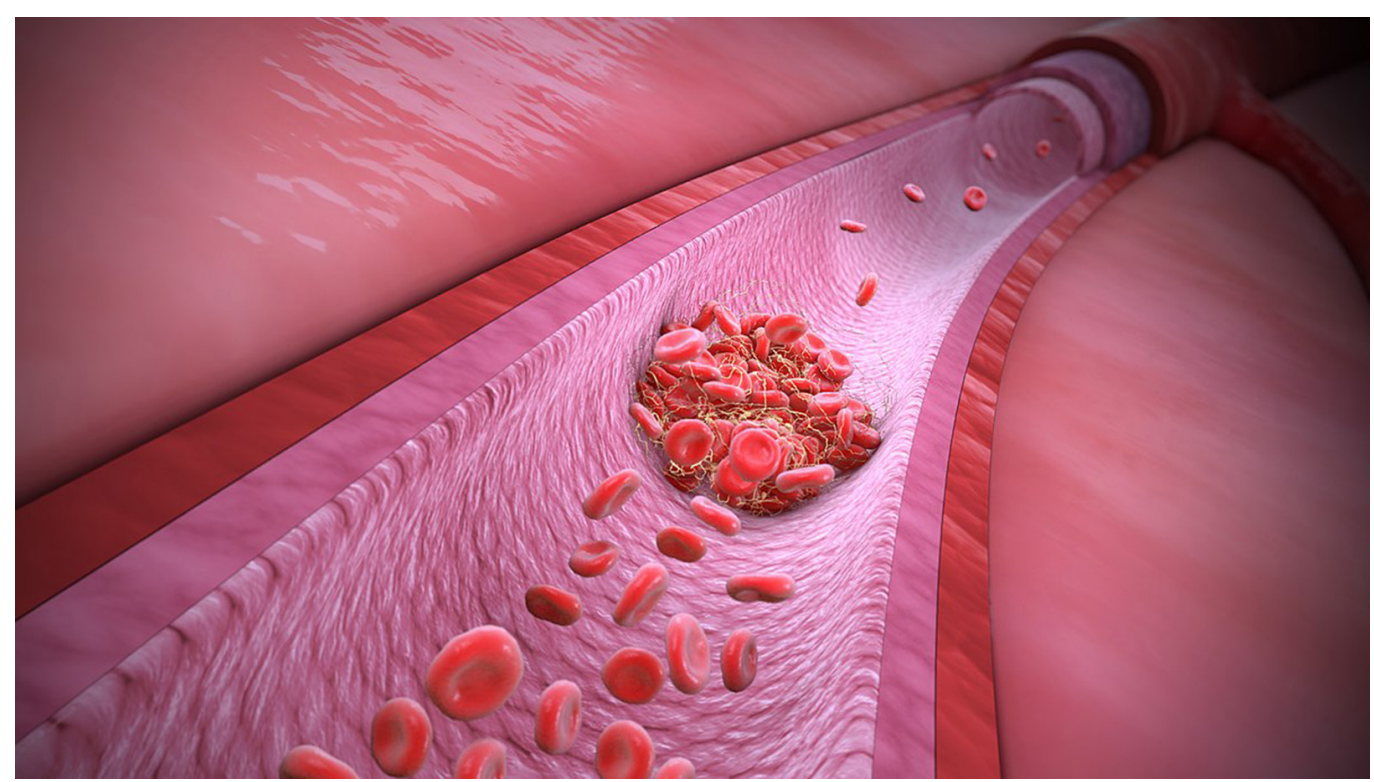

Fig. 10. Illustrazione medica 3D che spiega la trombosi nei vasi sanguigni, da: <https:// www.scientificanimations. $\mathrm{com} /$ wiki-images/> (consultato il 20 marzo 2021). 
strando come le diverse forme di illustrazione stiano acquisendo un ruolo importante nelle scienze mediche in quanto possono favorire la discussione e il confronto su temi complessi, sia in fase di prevenzione che di terapia. Lo sviluppo di questo filone di ricerca ha portato allo sviluppo di un ambito di indagine transdisciplinare riconoscibile con la definizione di "Medicina Grafica" [Green 20I0; Willims 20I I; Czerwiec et al. 20I5; Fartin, Priego 20I6] (fig. II).
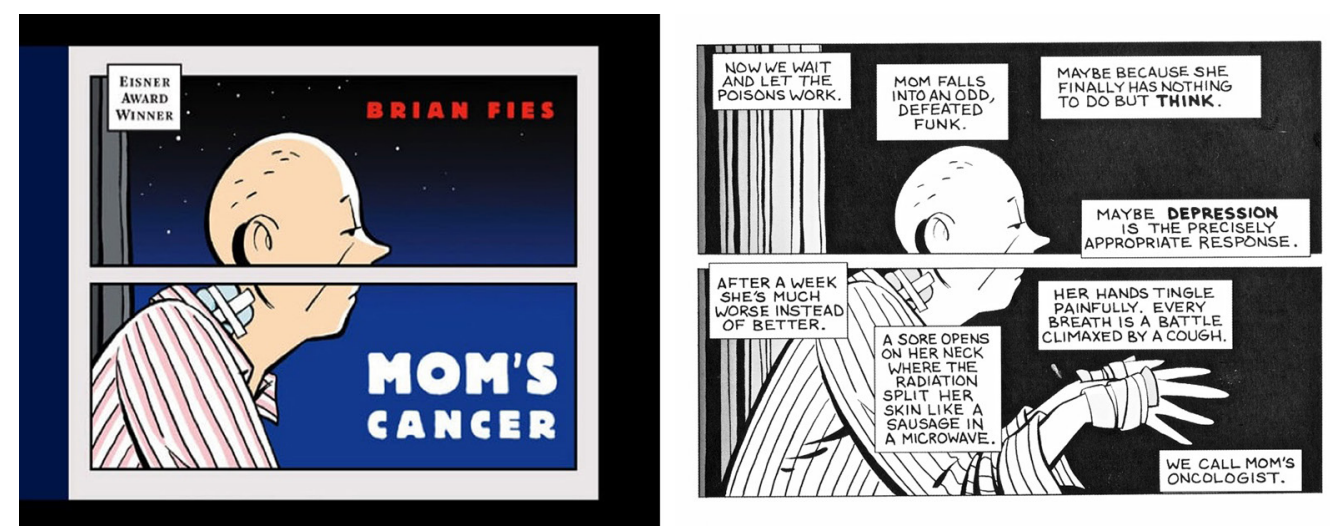

\section{Realtà Virtuale}

Lo sviluppo delle tecnologie VR potrà potenziare i tipi di esperienze che i visualizzatori che operano in ambito medico possono creare per favorire la formazione in ambito sanitario [Washington, Shaw 2019]. L'uso della realtà virtuale (VR) può infatti permettere a medici, assistenti, operatori sanitari e studenti di sperimentare in prima persona le frustrazioni e le percezioni dei pazienti con malattia o disabilità. L'esperienza VR può essere utile a insegnare efficacemente l'empatia e le capacità di comunicazione ai professionisti del settore medico in una dimensione completamente nuova. Percepire sensazioni quali la perdita dell'udito, la disabilità visiva, i problemi legati all'invecchiamento, permette ai medici e agli operatori di sperimentare le situazioni vissute dai pazienti, che altrimenti difficilmente potrebbero comprendere.

\section{Comunicazione}

Sensibilizzazione e coinvolgimento

II successo della ricerca in ambito medico dipende anche dalla percezione pubblica della sua utilità sociale ed è ormai noto come vi siano gruppi che non guardano con fiducia al progresso medico-scientifico. Questo fatto ha delle implicazioni su diversi fronti, come ad esempio sul reclutamento dei partecipanti alla ricerca e sulla comprensione dei risultati della ricerca stessa [Holzer et al. 20 I4]. Le immagini possono dare un contributo in tal senso, aumentando notevolmente l'attenzione e l'efficacia dei processi di comunicazione delle informazioni relative alle motivazioni e agli obiettivi dei progetti di ricerca, all'educazione alla salute, alle istruzioni sanitarie, influendo dunque sui comportamenti dei pubblici e in particolare di quelli con basse capacità di alfabetizzazione [Houts et al. 20 I5] (fig. I2).

\section{Conclusioni}

Dalla discussione presentata in questo articolo emerge come le distanze tra ambiti del sapere possano in realtà configurarsi come opportunità per lo sviluppo di nuovi percorsi di ricerca orientati alla connessione transdisciplinare. Un esempio è costituito dalle scienze grafiche e dalle scienze mediche, due campi del sapere chiaramente delineati che proprio dalla loro forte disciplinarietà traggono energia per la definizione di nuovi percorsi esplorativi. II confronto tra questi due ambiti rivela le possibilità di dialogo e le potenzialità di arricchimento reciproco ed 
evidenzia come la disponibilità di competenze grafico-visive all'interno dei gruppi di ricerca in ambito medico può potenziare i processi di ricerca e cura sotto molteplici punti di vista che vanno dalla fase di organizzazione della ricerca alla terapia, attraversando le fasi di interpretazione, divulgazione e formazione. Allo stesso tempo, lo sviluppo di competenze grafico-visive è strettamente legato al funzionamento del corpo e della mente umana, la cui conoscenza può sostenere, arricchire e stimolare la ricerca in ambito grafico-visivo. Così come le scienze grafiche possono contribuire ai progetti di ricerca in ambito medico, le scienze mediche possono aiutare l'avanzamento della ricerca in ambito grafico-visivo.

Si palesano in questo modo due possibilità operative per il raggiungimento degli obiettivi: una che vede la formazione di competenze multidisciplinari come quella del medico-illustratore, raggiungibile mediante la formazione in ambito grafico-visivo degli specialisti medici, l'altra che propone la definizione di gruppi di ricerca multidisciplinari in cui le diverse competenze restano separate ma collaborano per il conseguimento di obiettivi comuni. Entrambe le soluzioni si pongono in continuità con la storia dell'illustrazione scientifica che ha visto lo sviluppo parallelo delle due possibilità produttive delle visualizzazioni legate alla conoscenza: la prima che coincide con la figura dell'artista-scienziato e la seconda che vede invece la collaborazione e l'affiancamento tra le due figure dell'artista e dello scienziato. Entrambe le strade si dirigono verso un promettente campo di applicazione delle scienze grafiche e delle discipline del disegno, sia nell'ambito della ricerca che della didattica.

Fig. 12. Stefano Boeri, logo per la campagna vaccino anti-Covid-19. 2020.
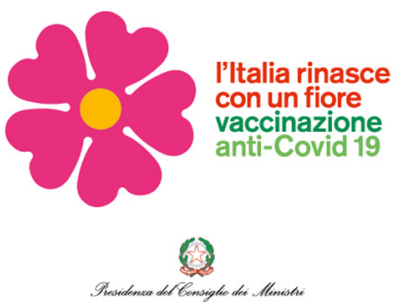

\section{Riferimenti bibliografici}

Austin P. E., Matlack R., Dunn K. A. et al. ( 1995). Discharge instructions: do illustrations help our patients understand them? In Annals of emergency medicine, 25(3), pp. 317-320.

Battulga B., Konishi T., Tamura Y., Moriguchi H. (2012). The effectiveness of an interactive 3-dimensional computer graphics model for medical education. In Interactive journal of medical research, I (2), <https://doi.org/I0.2 I 96/ijmr.2 I $72>$ (consultato il 20 marzo 202I).

Bergquist R., Rinaldi L. (20I0). Health research based on geospatial tools: a timely approach in a changing environment. In Journal of helminthology, 84.01 (2010), pp. I-II.

Bianchini C. (2019). Anatomographics. The Parallel Lives of Medical and Architectural Disciplines. In Cicalò E. (Ed.) International and Interdisciplinary Conference on Image and Imagination, pp. 804-816. Cham: Springer.

Bucher K. (20 I 6). New frontiers of medical illustration. In Jama, 3 I 6(22), pp. 2340-234 I.

Càndito C. (2020). Le macchine dell'architettura e del corpo umano e le loro illustrazioni tridimensionali. In Cicalò E. Trizio I. (a cura di) Linguaggi Grafici. Illustrazione. Alghero: PUBLICA.

Capone M., Lanzara E. (2020). Simulare per RI_Connettere. VR per i disturbi dello spettro autistico. In Arena A., Arena M., Brandolino R.G. et al. (eds.). Connecting. Drawing for weaving relationships, 42th Connecting. Drawing for weaving relationships. Proceedings of the 42th International Conference of Representation Disciplines Teachers. Milano: FrancoAngeli.

Casonato C. (2019). The skull and the cathedral: scientific illustration and architectural drawing in the 19th Century. In Belardi P. (a cura di). Riflessioni. L'arte del disegno/il disegno dell'arte. autore. $41^{\circ}$ Convegno internazionale dei Docenti delle discipline della Rappresentazione. Perugia 16-I 8 settembre 2019, pp. 57-64. Roma: Gangemi editore.

Connor J.T. (2009). Statistical graphics in AJG: save the ink for the information. In American Journal of Gastroenterology; 104 2009, pp. $1624-1630$.

Cringoli G. et al. (2005). Disease mapping and risk assessment in veterinary parasitology: some case studies. In Parassitologia, 47.I (2005), pp. 9-25.

Czerwiec M. K., Williams I., Squier S. M. et al. (20I5). Graphic Medicine Manifesto. Pennsylvania State: University Press.

Duke S. P., Bancken F., Crowe B. et al. (20I5). Seeing is believing: good graphic design principles for medical research. In Statistics in medicine, 34(22), pp. 3040-3059. 
Farthing A., Priego E. (20 I6).'Graphic Medicine'as a mental health information resource: Insights from comics producers. In The Comics Grid: Journal of Comics Scholarship, 6(3), pp. I-23.

Gearhart J. (20 I5). Clinical trial recruitment using social media is growing. In Quorum Review Institution Bulletin, 5 (I).

Gelinas L., Pierce R., Winkler S. et al. (2017). Using social media as a research recruitment tool: ethical issues and recommendations. In The American Journal of Bioethics, I7(3), pp. 3-I4.

Gelman A., Unwin A. (2013). Infovis and statistical graphics: different goals, different looks. In Journal of Computational and Graphical Statistics, 22(1), pp. 2-28.

Green M. J., Myers K.R. (20 I0). Graphic medicine: use of comics in medical education and patient care. In BMJ: British Medical Journal (Online), 340, 2010.

Hajar R. (201 I). Medical illustration: art in medical education. In Heart views: the official journal of the Gulf Heart Association, |2(2), p. 83-9|.

Hendrickx G., Biesemans J., de Deken R. (2004). The Use of GIS in Veterinary Parasitology. In Durr P., Gatrell. GIS and spatial analysis in veterinary science. Wallingford: CABI publishing.

Holzer J. K., Ellis L., Merritt M.W. (20।4). Why we need community engagement in medical research. In Journal of Investigative Medicine, 62(6), pp. 85 I-855.

Hout P. S., Doak C. C., Doak L. G., Loscalzo M. J. (2006). The role of pictures in improving health communication: a review of research on attention, comprehension, recall, and adherence. In Patient education and counseling, 6I (2), pp. I73- I 90.

Lawonn K., Smit N. N., Bühler K., Preim B. (20 I8). A survey on multimodal medical data visualization. In Computer Graphics Forum, Vol. 37, No. I, pp. 4I3-438.

Listorti J.A., Doumani, F. M. (200 I). Environmental Health: Bridging the Gaps. World Bank Discussion Paper, No. 422. Washington, DC: World Bank.

Parslow R., Elliot Green R. (eds.). ( 1971 ). Computer Graphics in Medical Research and Hospital Administration. LUOGO? Springer Science \& Business Media.

Pecora A. L. (2020) Virtual Environment for Autism. Drawing Space for Connection and Inclusion: an Open Debate. In Arena A., Arena M., Brandolino R.G., et al. (eds). Connecting. Drawing for weaving relationships, 42th International Conference of Representation Disciplines Teachers Congress of Unione Italiana per il Disegno. Proceedings 2020. Milano: FrancoAngeli.

Pocock S. J., Travison T. G., Wruck L. M. (2007). Figures in clinical trial reports: current practice \& scope for improvement. In Trials 2007; 8 pp. 36-53.

Preim B., Bartz D. (2007). Visualization in medicine: theory, algorithms, and applications. Burlington MA: Morgan Kauffman publisher. Prüss-.stün A., Corvalán C. (2007). How much disease burden can be prevented by environmental interventions? In Epidemiology, I8.I (2007), pp. I67-178.

Richardson D.B., et al. (20 I 3). Spatial turn in health research. In Science, 339.6126 (20 I 3), pp. I390- I 392.

Rinaldi L., et al. (2006). New insights into the application of geographical information systems and remote sensing in veterinary parasitology. In Geospatial Health, I.I (2006), pp. 33-47.

Topolovec-Vranic J., Natarajan K. (2016). The use of social media in recruitment for medical research studies: a scoping review. In Journal of medical Internet research, I 8(1 I), e286.

Tsafrir J., Ohry A. (200 I). Medical illustration: from caves to cyberspace. In Health Information \& Libraries Journal, I 8(2), pp. 99- I09.

Washington E., Shaw C. (2019) The Effects of a VR Intervention on Career Interest, Empathy, Communication Skills, and Learning with Second-Year Medical Students. In: Branch R., Lee H., Tseng S. (eds) Educational Media and Technology Yearbook. Educational Media and Technology Yearbook, vol 42. Springer, Cham.

Whitaker C., Stevelink S., Fear N. (2017). The use of Facebook in recruiting participants for health research purposes: a systematic review. In Journal of medical Internet research, 19(8), e290.

Williams I. C. (20I I). Graphic Medicine. Ars Medica, 8(I), 4.

\section{Autori}

Enrico Cicalò, Università degli Studi di Sassari, enrico.cicalo@uniss.it

Marta Pileri, Università degli Studi di Sassari, marta.pileri@gmail.com

Michele Valentino, Università degli Studi di Sassari, mvalentino@uniss.it

Per citare questo capitolo: Cicalò Enrico, Pileri Marta, Valentino Michele (2021). Connessione tra saperi. II contributo delle scienze grafiche nella ricerca in ambito medico/Connecting knowledge. The contribution of graphic sciences to medical research. In Arena A., Arena M., Mediati D. Raffa P. (a cura di). Connettere. Un disegno per annodare e tessere. Linguaggi Distanze Tecnologie. Atti del $42^{\circ}$ Convegno Internazionale dei Docenti delle Discipline della Rappresentazione/Connecting. Drawing for weaving relationship. Languages Distances Technologies. Proceedings of the $42^{\text {th }}$ International Conference of Representation Disciplines Teachers. Milano: FrancoAngeli, pp. 51 0-527. 


\title{
Connecting Knowledge. The Contribution of Graphic Sciences to Medical Research
}

\author{
Enrico Cicalò \\ Marta Pileri \\ Michele Valentino
}

\section{Abstract}

This article discusses the contribution of graphic sciences to research in the field of health and medicine and analyses the relationships between the two fields of knowledge by investigating the opportunities for interaction linked to the most current research perspectives. The article focuses on the various graphic-visual tools that can promote scientific progress and support research projects, presenting a state of the art on which to base relations of interaction between two fields that are apparently distant but which, as history shows us, can develop fertile synergies.

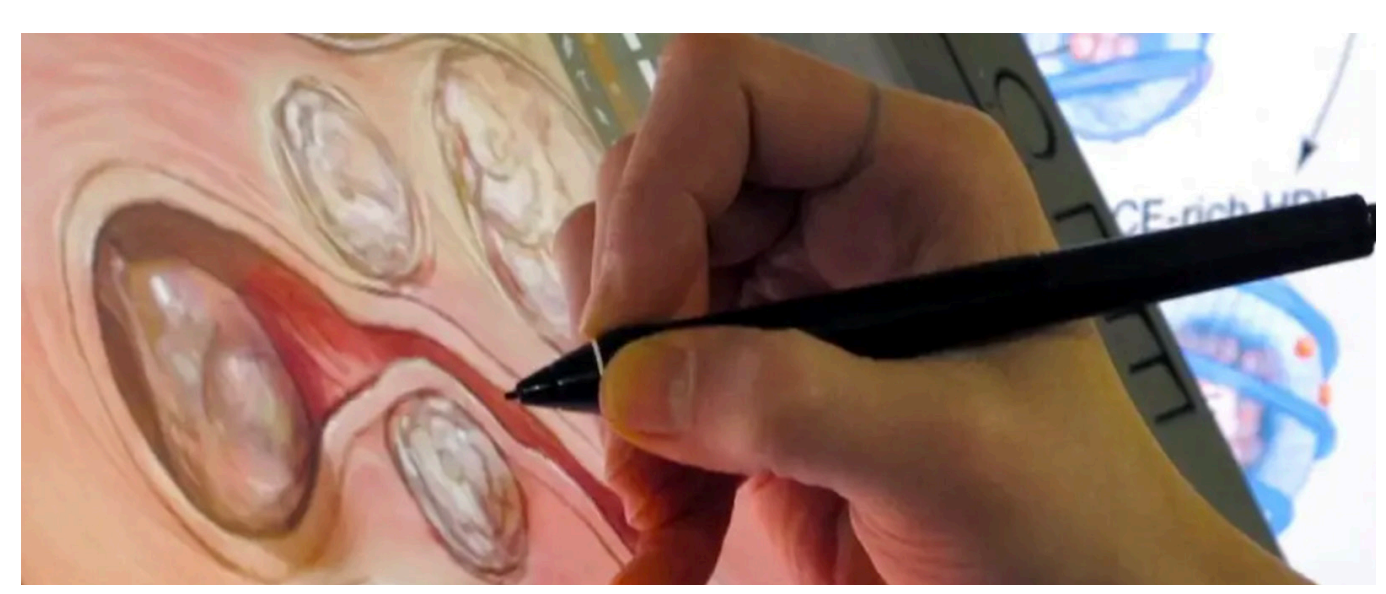


Because of their newness, emerging research topics are often located on the borderline between traditional fields of knowledge, in interstitial areas where an interdisciplinary approach is necessary, requiring the integration of multiple knowledge, disciplinary traditions, languages and sensibilities. This is the case of medical visualisation, an emerging and at the same time historically consolidated field of investigation, on the borderline between graphic and medical sciences.

Throughout the history of scientific thought, medical illustration has assumed a fundamental role in the construction and communication of knowledge, becoming an essential component of the methods of scientific investigation. Thus, it has become necessary for medical disciplines to adopt the tools of graphic representation in order to develop research, outlining new areas of investigation and new trans-disciplinary expertise involving graphic-visual skills.

Fig. I.The arterial system, folio 19, Ashmole Manuscript 399 , fol. 18 r. $13^{\text {th }}$ century, from: <www. cessed 2021, March 20)

Fig. 2. Andrea Vesalio, De humani corporis fabrica 543 , p. 197, from: <https://commons.wikimedia org/> (accessed 2021 March 20).
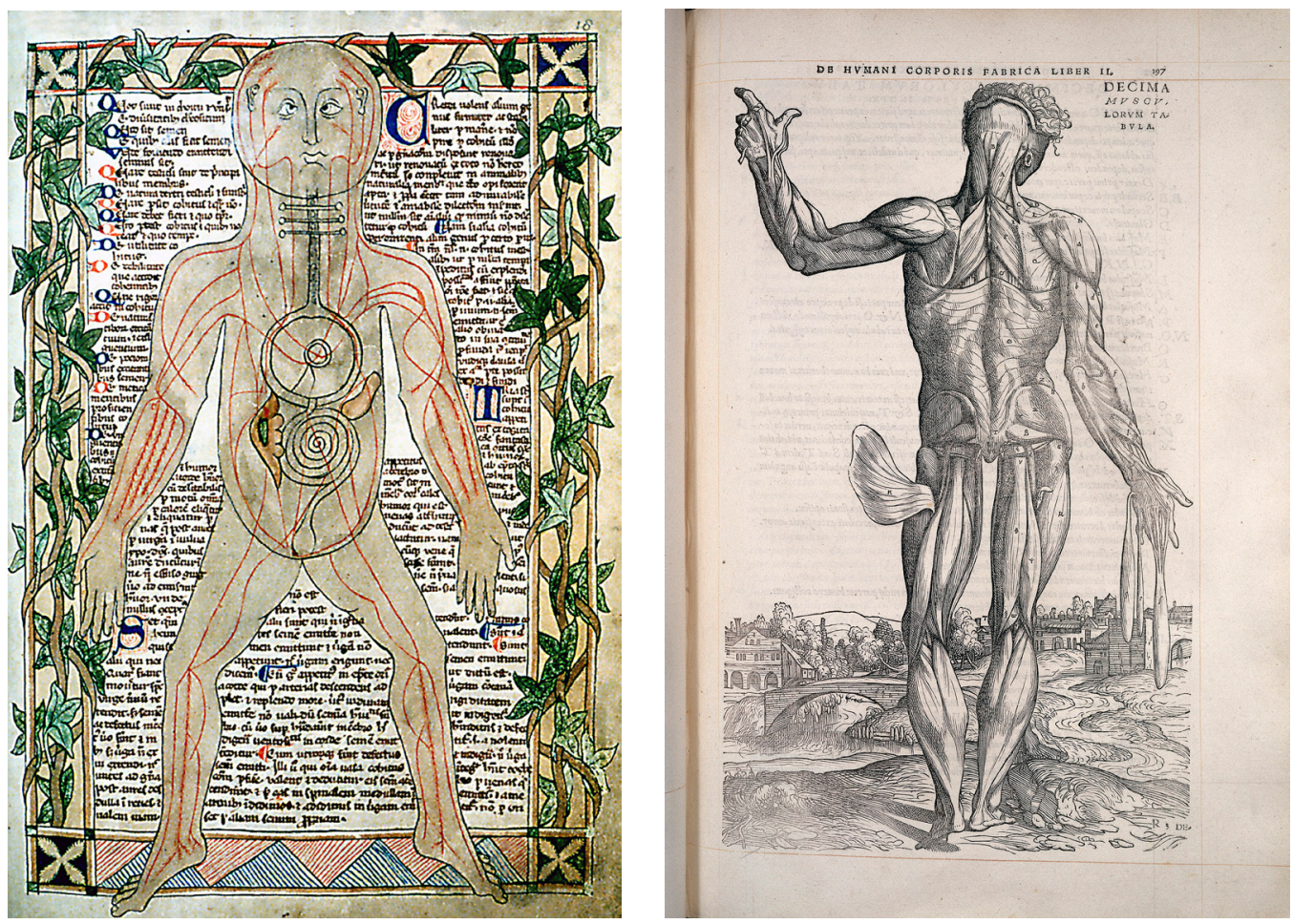

\section{Graphic sciences and medical sciences. \\ Connection between knowledge and disciplinary distances}

As the history and tradition of medical illustration demonstrates (figs. I-4), visualizations have always provided indispensable interfaces for exploring, understanding and communicating content in the field of healthcare [Hajar 20 I I].This type of graphical translation of knowledge has always facilitated the transmission of information by means of representations for different purposes: to visually translate and enhance the cognitive process, to involve in decision-making processes, to raise public awareness on medical and health issues of general interest and, finally, to disseminate and transmit scientific content.

The field of application of graphic sciences in the medical field is still at the centre of scientific debate today. 3D modelling, together with translations into 2D images for easy interpretation or for the creation of static, animated or interactive illustrations, is the latest 
evolution in the long history of medical-scientific illustration. In addition, a wide range of digital visualisation technologies including virtual and augmented reality, stereographic 3D and haptic devices are now being tested and applied in patient communication and training for physicians, diagnostics, visualization and medical simulation.

Researchers in the medical area are investigating how computer graphics can stimulate the progress of medical research [Parslow, Elliot Green 197 I]. However, although there is a strong international focus on the potential of medical visualization, it still appears to be not fully explored within the community of design researchers. Although the relationships between traditional architectural representation methods and tools and visualizations in the medical and anatomical fields have been discussed [Bianchini 2019; Casonato 2019, Càndito 2020], the possibilities of applying simulation techniques in relation to particular pathologies have been explored [Capone, Lanzara 2020; Pecora 2020] and a reflection on the contribution of graphic sciences in the medical field has been initiated [Cicalò,Valentino 2019], there is a field of investigation still largely to be explored that may have interesting perspectives both in research and in the teaching of Graphic Sciences.

Fig. 3. Leonardo da Vinci, the major organs and vascular and urine-genital system of a woman, $1507 \mathrm{ca}$, from: $<$ https $/ /$ comp (accessed 202 , March 20)

Fig. 4. Drawing of Purkinje cells (A) and granule cells (B) of the pigeon cerebellum, Santiago Ramón y Cajal, I 899. Instituto Santiago Ramón y Cajal, Madrid, Spain, from: $<$ https://commons.wikimedia org/> (accessed 2021. March 20)
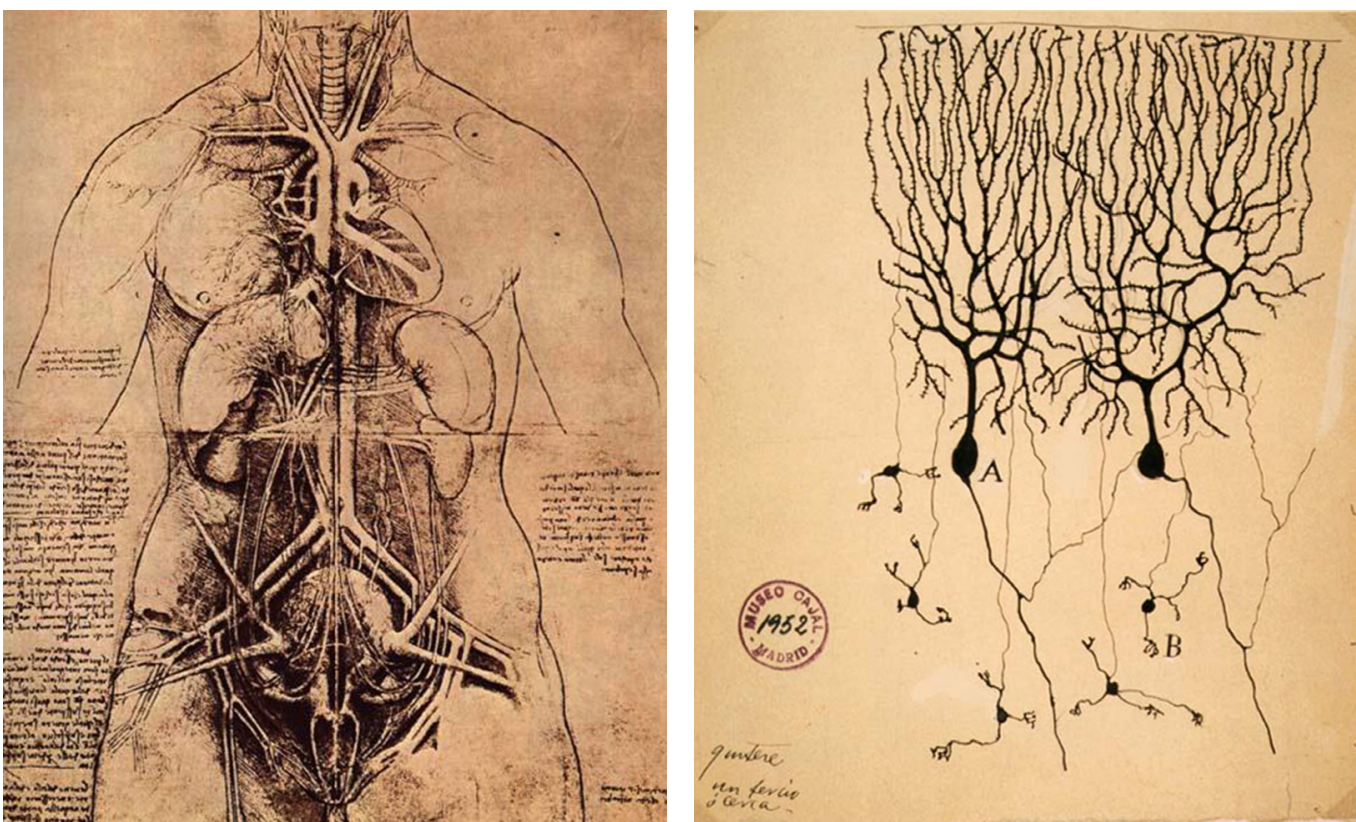

The contribution of graphic sciences to medical research

This article explores some of the main fields of application of the graphical disciplines in the medical sphere. Specific areas related to the mere acquisition of medical image data, linked to the use of tools capable of automatically returning images for medical diagnostics, are excluded from the discussion [cf. Lawonn, Smit, Bühler, Preim 20 I 8]. On the other hand, the focus is on all those fields in which graphic skills allow the creation of images by means of production and post-production techniques that require the application of the methods, techniques and tools of graphic representation and visual communication, thus belonging to the graphic sciences. In the knowledge that each of the categories of graphic-visual supports described below would merit an autonomous treatment, a picture is presented -not exhaustive but significant- of the possible contributions of the graphic sciences to research in the medical field, in an order which reflects their application in the various phases of medical research. 


\section{Data Collection}

Communication and promotion of collaborative research projects

The development of visual communication programs of research projects can contribute to the construction of research networks, especially in view of the fact that studies in the medical field can benefit from the call for action effect (fig. 5) conveyed through the web and social media, capable of expanding the number of subjects involved and therefore the study sample, especially for the involvement of participants not reachable through traditional channels and the consolidated networks [Topolovec-Vranic, Natarajan 20 I6]. Therefore, social media are emerging as useful communication channels to identify and recruit potential participants in clinical trials and other forms of research [Gearhart 20 I ; Gelinas et al. 2017; Whitaker, Stevelink, Fear 2017] through the dissemination of visual content, which due to its immediacy and readability can make a significant contribution to communication and dissemination processes [Cicalò 20I8].

\section{Data Interpretation}

Visualization of medical data

The development of graphical aids to visualise statistical data and information gathered during research can facilitate the interpretation of results and support decision-making. Although there is a consensus within the medical community that images can be a powerful means of communication, there is still a need to invest in research in the specific field of visualisation [Connor 2009; Gelman, Unwin 20 I3; Pocock, Travison, Wruck 2007]. In fact, it is necessary to be able to carefully choose the most effective visualisation and the most appropriate type of illustration, to respect the fundamental principles of visual communication [Cicalò, Menchetelli 2020] through the involvement of disciplines outside the medical area and to invest more in the creation of visualisations that may require a greater effort, but that can contribute to the improvement of the communication of research results to support decision-making processes [Duke et al. 20 I5] (fig. 6).

Fig. 5. Visual abstract for the social campaign aimed at recruiting operating units to participate in the 'dedilaco' research regarding laparoscopic cholecystectomy that involves the collaboration of the authors as visualizers responsible for communication, infographics and data visualization (2020).

Fig. 6. Omar Nema, Abhi Kumbara, Data visualization on the relationships between cost, hospital size quality of outcomes, and quality of outcomes, and patient experience, 2016, (acm: <htps.//arcadia.io/> 20).

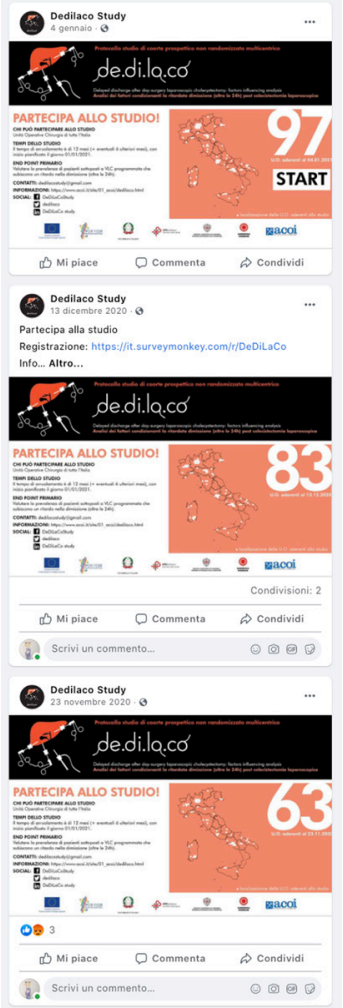

LOW COST HOSPITALS

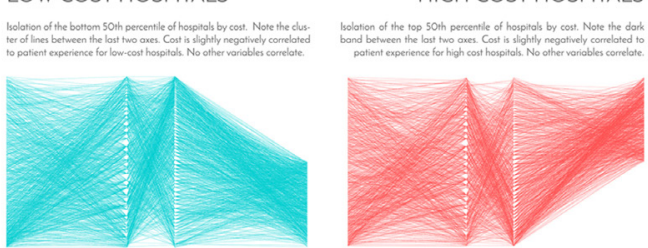


Health Maps

An important aspect of health research is the study of risk factors for diseases that are considered 'environmental' because they are linked to factors dependent on the physical context [Listorti, Doumani 200I; Prüssstün, Corvalan 2007]. Disease mapping and environmental risk assessment based on geospatial data has become an established method [Bergquist, Rinaldi 20 I0; Richardson et al. 20I3]. Geographic information systems (GIS), remote sensing (RS), geographic positioning systems (GPS), spatial statistics and other digital applications have made it possible to translate data sets collected in the course of medical research into maps. Thus, GIS has become established as a useful tool for collecting, exploring, visualising and analysing health data graphically [Hendrickx et al. 2004; Cringoli et al. 2005; Yang et al. 2005; Rinaldi et al. 2006; Brooker 2007] (fig. 7). Furthermore, in the last decade, a specialised scientific publication on these topics has developed, which has led to the emergence of dedicated journals such as the International Journal of Health Geographics and Geospatial Health.

Fig. 7. Map for analysis and monitoring of Covid 9-related phenomena, com/> (accessed 2021 March 20).

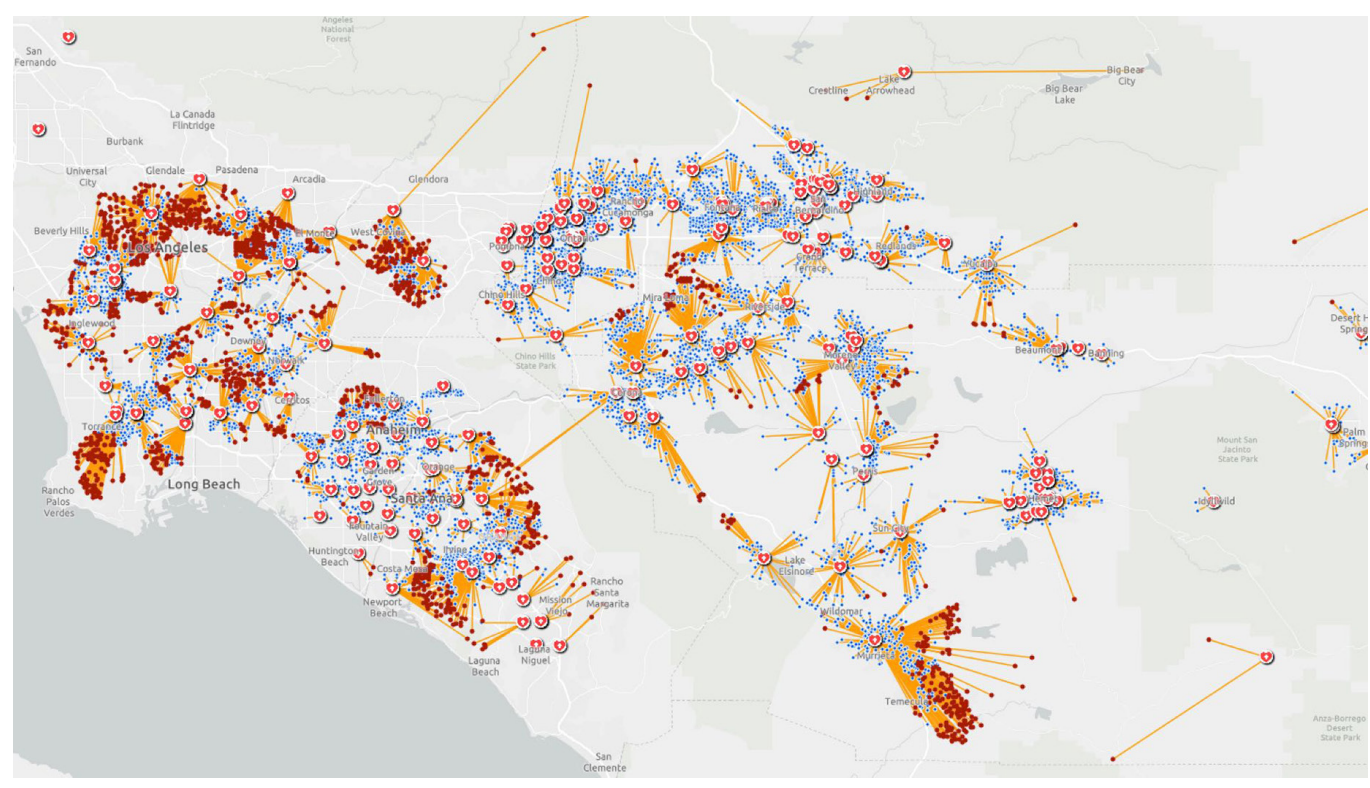

Dissemination of results

Medical illustrations

The depiction of the human body has always been central to the development of knowledge representation, from cave paintings and primitive sculptures to the present day. With scientific progress, medical texts began to be accompanied by illustrations that became an integral part of the process of transmitting knowledge. Illustrators have thus worked alongside physicians to divulge their studies and discoveries, and sometimes the two figures -of the illustrator and the scientist- have coincided, defining a new professional profile and a disciplinary field apart [Tsafrir, Ohry $200 \mathrm{I}]$. This is also testified by various specialised publications such as the Journal of Visual Communication in Medicine of the Institute of Medical Illustrators, The Journal of Biocommunication of the Association of Medical Illustrators and the BioCommunications Association. Today, static illustration is still a popular visual communication format, but the medical-illustrator community now also includes animators, modellers, user-experience designers, multimedia specialists, art directors and other types of medical-scientific visualisers [Bucher 20।6] (figs. 8, 9). 
Fig. 8. Medical illustration by Victoria Mulloc (from: Association Européenne des Illustrateurs Médicaux et Scientifiques: <https:// www.aeims.eu/artists/> accessed 2021, March 20).

Fig. 9. Medical Illustration by (by: Association Européenne des

Illustrateurs Médicaux et Scientifiques: <https:// www.aeims.eu/artists/> accessed 2021, March
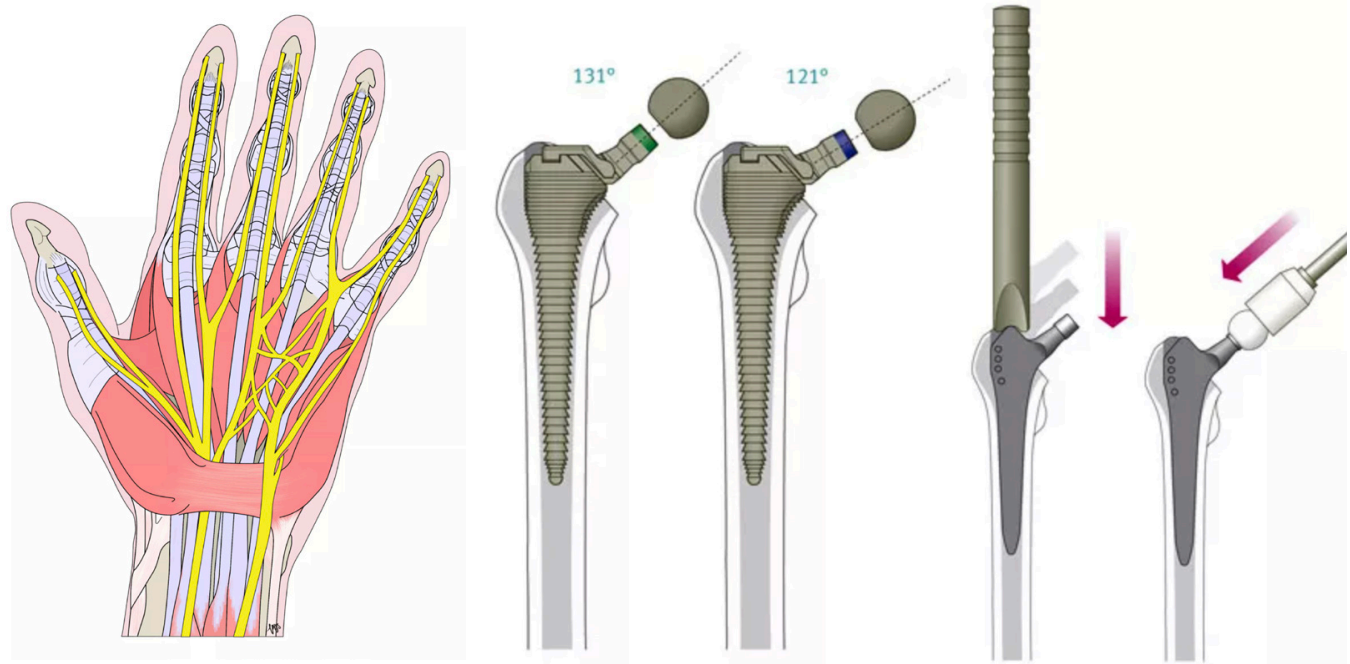

Anatomical three-dimensional visualizations

Medical visualisations can be included in a specific field that is part of the broader scientific visualisation that has its roots in anatomical illustration and is now expressed in computer graphics, through which three-dimensional geometric data and algorithms useful for representation can be acquired and stored [Preim, Bartz 2007]. Three-dimensional visualisation techniques can be used in diagnosis, treatment planning, doctor-patient communication [Lawoon et al. 20 I8], in training students who can better understand the complexity of anatomical structure [Battulga et al. 20 I2] (fig. I0) and more generally in analysis and clinical research [Parslow, Elliot Green I97I].

\section{Therapy}

Visual communication in doctor-patient interaction

The development of visual aids to patient communication can facilitate the transmission of content in doctor-patient communication (Austin et al. 1995). The use of graphic narratives has been discussed and tested in the medical field by various researchers, demonstrating how different forms of illustration are acquiring an important role in the medical

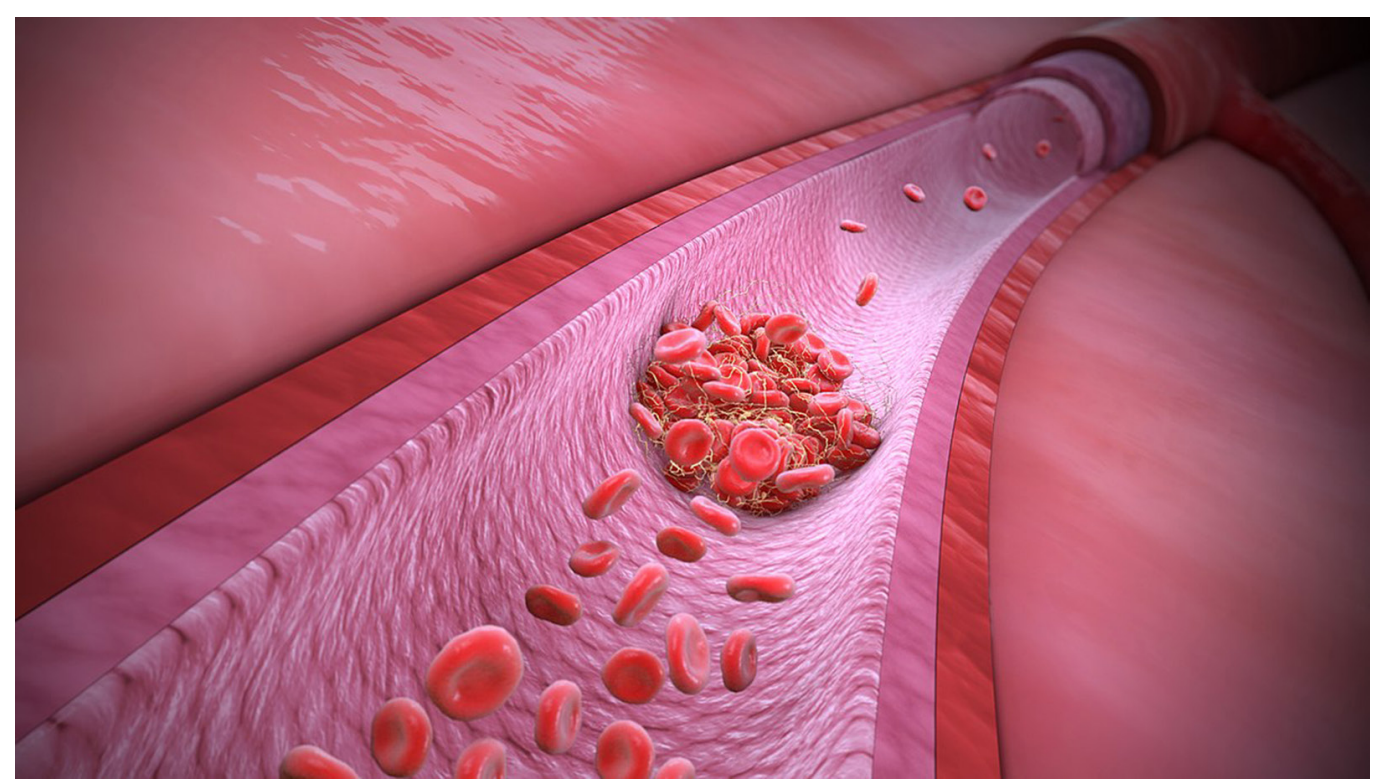


Fig. I I. Cover and inside page of the book Mom's cancer, by Brian Fies, 2006. sciences as they can encourage discussion and debate on complex issues, both in the prevention and treatment phases. The development of this research field has led to the development of a transdisciplinary field of investigation which can be identified by the term 'Graphic Medicine' [Green 2010; Willims 201 I; Czerwiec et al. 20 I5; Fartin, Priego 20l6] (fig. I I).
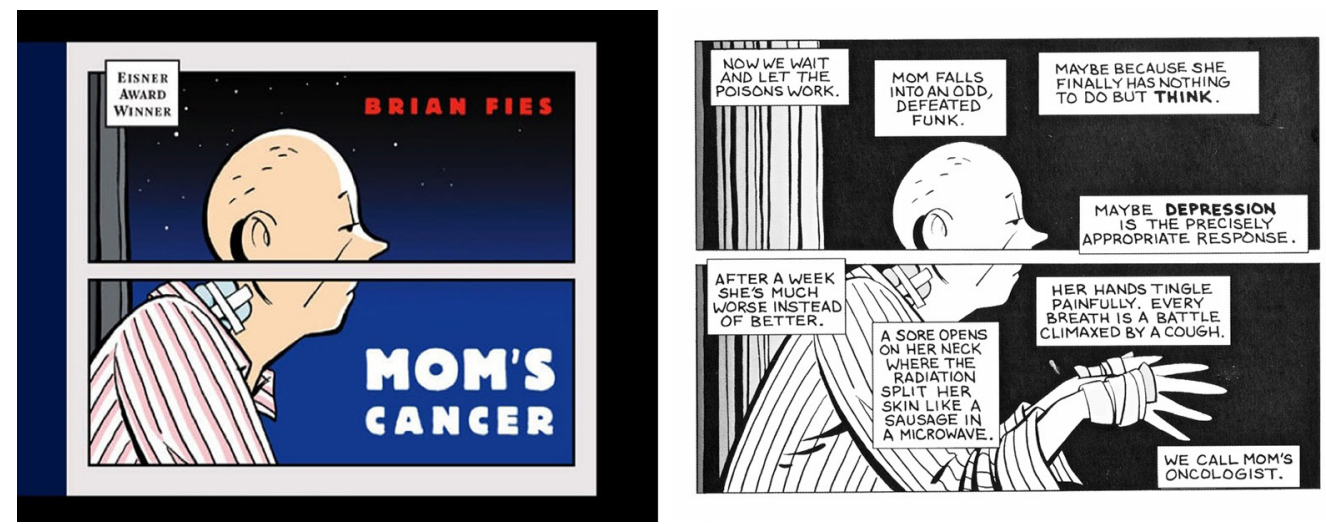

\section{Virtual Reality}

The development of $\mathrm{VR}$ technologies will be able to enhance the types of experiences that medical viewers can create to further healthcare education [Washington, Shaw 2019]. Indeed, the use of virtual reality (VR) can allow physicians, caregivers, healthcare professionals, and students to experience firsthand the frustrations and perceptions of patients with illness or disability. The VR experience can be useful in effectively teaching empathy and communication skills to medical professionals in a whole new dimension. Perceiving sensations such as hearing loss, visual impairment, and problems related to ageing, allows doctors and practitioners to experience situations experienced by patients that they would otherwise find difficult to understand.

\section{Communication}

Awareness and involvement

The success of medical research also depends on the public perception of its social usefulness and it is well known that there are groups that do not look with confidence on medical and scientific progress. This has implications on a number of fronts, such as the recruitment of research participants and the understanding of research findings (Holzer et al. 2014). Images can make a contribution in this regard, significantly increasing the attention and effectiveness of processes for communicating information about the motivations and objectives of research projects, health education, and health instructions, thus influencing the behaviour of audiences and particularly those with low literacy skills [Houts et al. 20 15] (fig. I2).

\section{Conclusions}

From the discussion presented in this article it emerges how the distances between fields of knowledge can in fact be seen as opportunities for the development of new research approaches oriented towards transdisciplinary connections. One example is the graphic sciences and the medical sciences, two clearly delineated fields of knowledge that take strength from their strong disciplinary nature to define new exploratory possibilities. The comparison between these two fields reveals the possibilities for dialogue and the poten- 
tial for mutual enrichment, and shows how the availability of graphic-visual skills in medical research groups can enhance the research and treatment processes from multiple points of view, from the organization of research to therapy, through the phases of interpretation, dissemination and training. At the same time, the development of graphic-visual skills is closely linked to the functioning of the human body and mind, the knowledge of which can support, enrich and stimulate research in graphic-visual science. Just as graphic sciences can contribute to medical research projects, medical sciences can help advance graphic-visual research.

In this way, it is possible to identify two operational possibilities for achieving the objectives: one that involves the formation of multidisciplinary skills such as that of the medical illustrator, which can be achieved through the training of medical specialists in the field of graphics and visuals, and the other that proposes the organization of multidisciplinary research groups in which the various skills remain separate but work together to achieve common objectives. Both solutions are in continuity with the history of scientific illustration, which has seen the parallel development of the two productive possibilities of visualizations linked to knowledge: the first coinciding with the figure of the artist-scientist and the second seeing the collaboration and side-by-side between the two figures of the artist and the scientist. Both paths lead towards a promising field of application of graphic sciences and drawing disciplines, both in research and teaching.
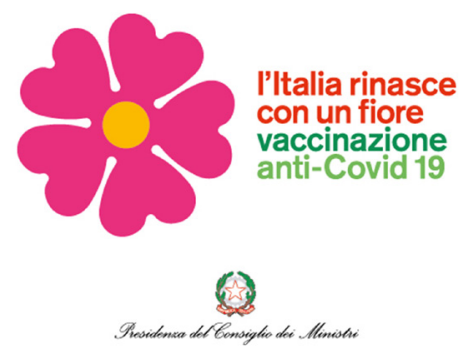

\section{References}

Austin P. E., Matlack R., Dunn K. A. et al. (1995). Discharge instructions: do illustrations help our patients understand them? In Annals of emergency medicine, 25(3), pp. 317-320.

Battulga B., Konishi T., Tamura Y., Moriguchi H. (2012). The effectiveness of an interactive 3-dimensional computer graphics model for medical education. In Interactive journal of medical research, I (2), <https://doi.org/I0.2 I 96/ijmr.2 I 72> (consultato il 20 marzo 2021).

Bergquist R., Rinaldi L. (2010). Health research based on geospatial tools: a timely approach in a changing environment. In Journal of helminthology, 84.01 (2010), pp. I- II.

Bianchini C. (2019). Anatomographics. The Parallel Lives of Medical and Architectural Disciplines. In Cicalò E. (Ed.) International and Interdisciplinary Conference on Image and Imagination, pp. 804-8I 6. Cham: Springer.

Bucher K. (2016). New frontiers of medical illustration. In Jama, 3 I 6(22), pp. 2340-234I.

Càndito C. (2020). Le macchine dell'architettura e del corpo umano e le loro illustrazioni tridimensionali. In Cicalò E. Trizio I. (a cura di) Linguaggi Grafici. Illustrazione. Alghero: PUBLICA.

Capone M., Lanzara E. (2020). Simulare per RI_Connettere. VR per i disturbi dello spettro autistico. In Arena A., Arena M. Brandolino R.G. et al. (eds.). Connecting. Drawing for weaving relationships, 42th Connecting. Drawing for weaving relationships. Proceedings of the 42th International Conference of Representation Disciplines Teachers. Milano: FrancoAngeli.

Casonato C. (2019). The skull and the cathedral: scientific illustration and architectural drawing in the 19th Century. In Belardi P. (a cura di). Riflessioni. L'arte del disegno/il disegno dell'arte. autore. $41^{\circ}$ Convegno internazionale dei Docenti delle discipline della Rappresentazione. Perugia 16-18 settembre 2019, pp. 57-64. Roma: Gangemi editore.

Connor J. T. (2009). Statistical graphics in AJG: save the ink for the information. In American Journal of Gastroenterology; I04, 2009, pp. $1624-1630$

Cringoli G. et al. (2005). Disease mapping and risk assessment in veterinary parasitology: some case studies. In Parassitologia, 47.I (2005), pp. 9-25.

Czerwiec M. K., Williams I., Squier S. M. et al. (20I5). Graphic Medicine Manifesto. Pennsylvania State: University Press. 
Duke S. P., Bancken F., Crowe B. et al. (20I5). Seeing is believing: good graphic design principles for medical research. In Statistics in medicine, 34(22), pp. 3040-3059.

Farthing A., Priego E. (20 I6). 'Graphic Medicine'as a mental health information resource: Insights from comics producers. In The Comics Grid: Journal of Comics Scholarship, 6(3), pp. I-23.

Gearhart J. (20I5). Clinical trial recruitment using social media is growing. In Quorum Review Institution Bulletin, 5 (I).

Gelinas L., Pierce R., Winkler S. et al. (2017). Using social media as a research recruitment tool: ethical issues and recommendations. In The American Journal of Bioethics, I7(3), pp. 3-I4.

Gelman A., Unwin A. (2013). Infovis and statistical graphics: different goals, different looks. In Journal of Computational and Graphical Statistics, 22(I), pp. 2-28.

Green M. J., Myers K.R. (20 I0). Graphic medicine: use of comics in medical education and patient care. In BMJ: British Medical Journal (Online), 340, 2010.

Hajar R. (201 I). Medical illustration: art in medical education. In Heart views: the official journal of the Gulf Heart Association, 12(2), p. 83-91.

Hendrickx G., Biesemans J., de Deken R. (2004). The Use of GIS in Veterinary Parasitology. In Durr P., Gatrell. GIS and spatial analysis in veterinary science. Wallingford: CABI publishing.

Holzer J. K., Ellis L., Merritt M.W. (2014). Why we need community engagement in medical research. In Journal of Investigative Medicine, 62(6), pp. 85 I-855

Hout P. S., Doak C. C., Doak L. G., Loscalzo M. J. (2006). The role of pictures in improving health communication: a review of research on attention, comprehension, recall, and adherence. In Patient education and counseling, 6I (2), pp. I73-I90.

Lawonn K., Smit N. N., Bühler K., Preim B. (2018). A survey on multimodal medical data visualization. In Computer Graphics Forum, Vol. 37, No. I, pp. 413-438.

Listorti J. A., Doumani, F. M. (200 I). Environmental Health: Bridging the Gaps. World Bank Discussion Paper, No. 422. Washington, DC:World Bank.

Parslow R., Elliot Green R. (eds.). ( 197 I). Computer Graphics in Medical Research and Hospital Administration. LUOGO? Springer Science \& Business Media.

Pecora A. L. (2020) Virtual Environment for Autism. Drawing Space for Connection and Inclusion: an Open Debate. In Arena A., Arena M., Brandolino R.G., et al. (eds). Connecting. Drawing for weaving relationships, 42th International Conference of Representation Disciplines Teachers Congress of Unione Italiana per il Disegno. Proceedings 2020. Milano: FrancoAngeli.

Pocock S. J., Travison T. G., Wruck L. M. (2007). Figures in clinical trial reports: current practice \& scope for improvement. In Trials 2007; 8 pp. 36-53.

Preim B., Bartz D. (2007). Visualization in medicine: theory, algorithms, and applications. Burlington MA: Morgan Kauffman publisher. Prüss-.stün A., Corvalán C. (2007). How much disease burden can be prevented by environmental interventions? In Epidemiology, I8.I (2007), pp. 167-178.

Richardson D.B., et al. (20 I3). Spatial turn in health research. In Science, 339.6126 (20 I 3), pp. I 390 - I 392.

Rinaldi L., et al. (2006). New insights into the application of geographical information systems and remote sensing in veterinary parasitology. In Geospatial Health, I.I (2006), pp. 33-47.

Topolovec-Vranic J., Natarajan K. (2016). The use of social media in recruitment for medical research studies: a scoping review. In Journal of medical Internet research, I 8(I I), e286.

Tsafrir J., Ohry A. (200 I). Medical illustration: from caves to cyberspace. In Health Information \& Libraries Journal, I8(2), pp. 99- I09.

Washington E., Shaw C. (2019) The Effects of a VR Intervention on Career Interest, Empathy, Communication Skills, and Learning with Second-Year Medical Students. In: Branch R., Lee H., Tseng S. (eds) Educational Media and Technology Yearbook. Educational Media and Technology Yearbook, vol 42. Springer, Cham.

Whitaker C., Stevelink S., Fear N. (2017). The use of Facebook in recruiting participants for health research purposes: a systematic review. In Journal of medical Internet research, 19(8), e290.

Williams I. C. (20I I). Graphic Medicine. Ars Medica, 8(I), 4.

\section{Authors}

Enrico Cicalò, Università degli Studi di Sassari, enrico.cicalo@uniss.it

Marta Pileri, Università degli Studi di Sassari, marta.pileri@gmail.com

Michele Valentino, Università degli Studi di Sassari, mvalentino@uniss.it

To cite this chapter. Cicalò Enrico, Pileri Marta,Valentino Michele (2021). Connessione tra saperi. Il contributo delle scienze grafiche nella ricerca in ambito medico/Connecting knowledge. The contribution of graphic sciences to medical research. In Arena A., Arena M., Mediati D., Raffa P. (a cura di). Connettere. Un disegno per annodare e tessere. Linguaggi Distanze Tecnologie. Atti del $42^{\circ}$ Convegno Internazionale dei Docenti delle Discipline della Rappresentazione/Connecting. Drawing for weaving relationship. Languages Distances Technologies. Proceedings of the $42^{\text {th }}$ International Conference of Representation Disciplines Teachers. Milano: FrancoAngeli, pp. 510-527. 